\title{
RESEARCH NOTE \\ Sustainability of Quinoa in Rainfed Agricultural Systems: A Case Study on the O'Higgins Region, Chile
}

\author{
Pablo Olguín, Alejandro De Kartzow, and Carlos Huenchuleo \\ Pontificia Universidad Católica de Valparaíso, Escuela de Agronomía. Casilla 4-D \\ Quillota, Chile. La Palma S/N, San Francisco, Quillota, Región de Valparaíso, Chile.
}

\begin{abstract}
P. Olguín, A. De Kartzow, and C. Huenchuleo. 2019. Sustainability of Quinoa in Rainfed Agricultural Systems: A Case Study on the O'Higgins Region, Chile. Cien. Inv. Agr. 46(2): 197-207. Quinoa is a grain that has seen a rapid consumption boom in recent years. Chile has also followed this trend through quinoa consumption associated with a healthy diet and environmental care. The correlation between quinoa crops and farming sustainability lays mainly in the actions and expertise of the agents involved in the decision-making process, who depend on the available experience and knowledge. Multicriteria decision analysis is a set of support techniques in the decision-making process. It consists of directing multiple opinions and assessment criteria, in specific actions, validated by an interest group. This study is based on the definition and weighting of the criteria that influence the sustainability of quinoa as a crop in contrast with the wheat as the most important crop in the rainfed area, taking into account the opinions of farmers and other parties involved. The findings are the weighting of the criteria of the following variables: contribution to family income, ease of sales, positive impact on the environment, production cost savings, knowledge of the crop, and government support. The model helped to create a quantitative basis for the sustainability potential of quinoa as a booming crop and as an alternative for the traditional wheat crop in farming.
\end{abstract}

Keywords: Comparative advantage, ecosystem, reconversion.

\section{Introduction}

The United Nations declared 2013 as the international year of quinoa; this raised new hopes about its potential to contribute to a healthy diet. This announcement was accompanied by strategy of dissemination throughout the five continents that

Received Apr 21, 2019. Accepted Jun 12, 2019. Corresponding author: alejandro.dekartzow@pucv.cl aimed to promote quinoa consumption worldwide (FAO, 2014). Quinoa can be of great help in the daily diet of vegetarians and people with diabetes and celiac disease. Moreover, many studies show that quinoa crops are water-stress resistant and tolerant to soil salinity (Fuentes, 2008). These characteristics of quinoa crops have attracted the attention of researchers because they make quinoa a viable alternative for agriculture. Currently, farming is limited by climate change and by soil degradation phenomena (FIA, 2017). 
At the international level, there has been a progressive increase in quinoa crop production and demand. It is estimated that Bolivia, Ecuador, and Peru together account for $80 \%$ of global production. This increase in cultivation areas has occurred not only in the main producer countries but also in countries from the Southern Cone, such as Argentina, Brazil, Chile, and Colombia. Moreover, many studies and productive tests of different scales have been carried out outside the Americas seeking to introduce quinoa as a crop (FIA, 2017).

In Chile, it was estimated that during the 2015-2016 crop season, quinoa production reached 620 tons; it was cultivated over an area of 706 hectares, with an average yield of 1.0 tons ha-1 (FIA, 2017). In this context, many of the producers in Chile are located in the regions of Tarapaca, Valparaiso, O'Higgins, and Araucania. A clear sign of the increasing relevance of quinoa crops in Chile is that a public-private board was established in November 2012. At the time of this publication, many work subcommittees have been established to tackle the creation and development of the "Chilean Quinoa" mark both locally and internationally, the improvement of the profitability of the crop, the coordination of parties involved in chain value and fair and sustainable trade (Pefaur, 2018).

According to data gathered by Fundación para la Innovación Agraria (FIA, 2017), the rainfed area of the O'Higgins region accounts for $53 \%$ of Chilean production, and this is where the ecotype "coastal area or lowland area" develops. There are approximately 100 quinoa producers in the O'Higgins region, and they are family farmers in the towns of Marchigüe, Paredones, Pichilemu, and Pumanque.

To assess the sustainability of quinoa as a crop in rainfed farming systems, it must be compared with another crop with similar environmental requirements that must be a viable alternative in terms of productive resource allocation. Previous studies have documented that wheat is one of the primary candidates for agricultural production in the rainfed O'Higgins region (Bazile et al., 2013).

Bearing this analytic framework in mind, farmers, technical professionals, government officials, and scholars must identify the potential change from wheat crops to quinoa crops. However, it is not a simple solution. There are many factors involved in the decision-making process of choosing quinoa over wheat; one example is the importance of cultural, economic and environmental factors described in Pantoja et al. (2017).

Multicriteria decision analysis (MCDA) is a set of support techniques for decision making that provides a framework. It consists of different opinions and criteria for assessment and the appropriate methodological framework (Pantoja, 2017; Malczweski, 2006). This method has been applied in many related studies, e.g., to assess an alternative for the long cycles of continuous monoculture in Valle de Lerma in the plains of the Salta Mountains in northwest Argentina (Chavez et al., 2012), to identify an apple variety with the highest resistance to pests and diseases in eastern Slovenia (Rozman et al., 2015), and to assess the suitability of apitourism in the O'Higgins region, Chile (Pantoja et al., 2017), to name a few.

Our study suggests that in the rainfed area of the O'Higgins region, the decision regarding quinoa or wheat crops depends on economic, technical, political and environmental factors.

The primary objective of this study was to determine the sustainability of land use for the cultivation of wheat and quinoa crops in the rainfed area of the O'Higgins region using the MCDA method. The study presents an empiric method for quantifying the decision-making process to identify and assess the weightings related to economic, technical, political and environmental criteria. The findings of this case study are the first regarding quinoa carried out in the rainfed area of the O'Higgins region in Chile. 


\section{Materials and Methods}

\section{Study Area}

The studied area (Figure 1) comprises the towns of Marchigüe, Paredones, Pichilemu, and Pumanque. All of these towns are located in the rainfed area of the O'Higgins region (lat. 34³2' 35'; long. $\left.71^{\circ} 39^{\prime} 51^{\prime \prime}\right)$ in the central area of Chile. This area has a Mediterranean climate, with rains in winter, mild temperatures and an extended dry summer season (Di Castri y Hajek, 1976). The average annual rainfall is approximately $500-650 \mathrm{~mm}$, normally distributed from April to August (Bazile et al., 2013). There are also seven months with rainfall of less than $40 \mathrm{~mm}$, generally occurring from October to April. The coastal mountain range limits the maritime influence; thus, fewer cloudy days are observed in comparison to coastal zones. The climate of the studied towns is under the influence of the coastal line of the Pacific Ocean, which moderates extreme temperatures. Farm production is characterized by its occurrence at an altitude varying from 0 to 800 masl under rainfed conditions (Fuentes et al., 2012).

Despite having suffered an important reduction in farming areas in recent decades due to an increase in the areas dedicated to forest plantations (conifers), some farmers cultivate quinoa as a family tradition instead of wheat, potato and legumes, which are the predominant crops in the area (Alfonso, 2008). Farmers who plant extensive areas (approximately $10 \mathrm{ha}$ ) are landowners. The remaining farmers lease their farming land.

In some cases, they have agreements by which they share a certain percentage of their production (sharecropping). Some farmers also have additional jobs apart from crop cultivation (in

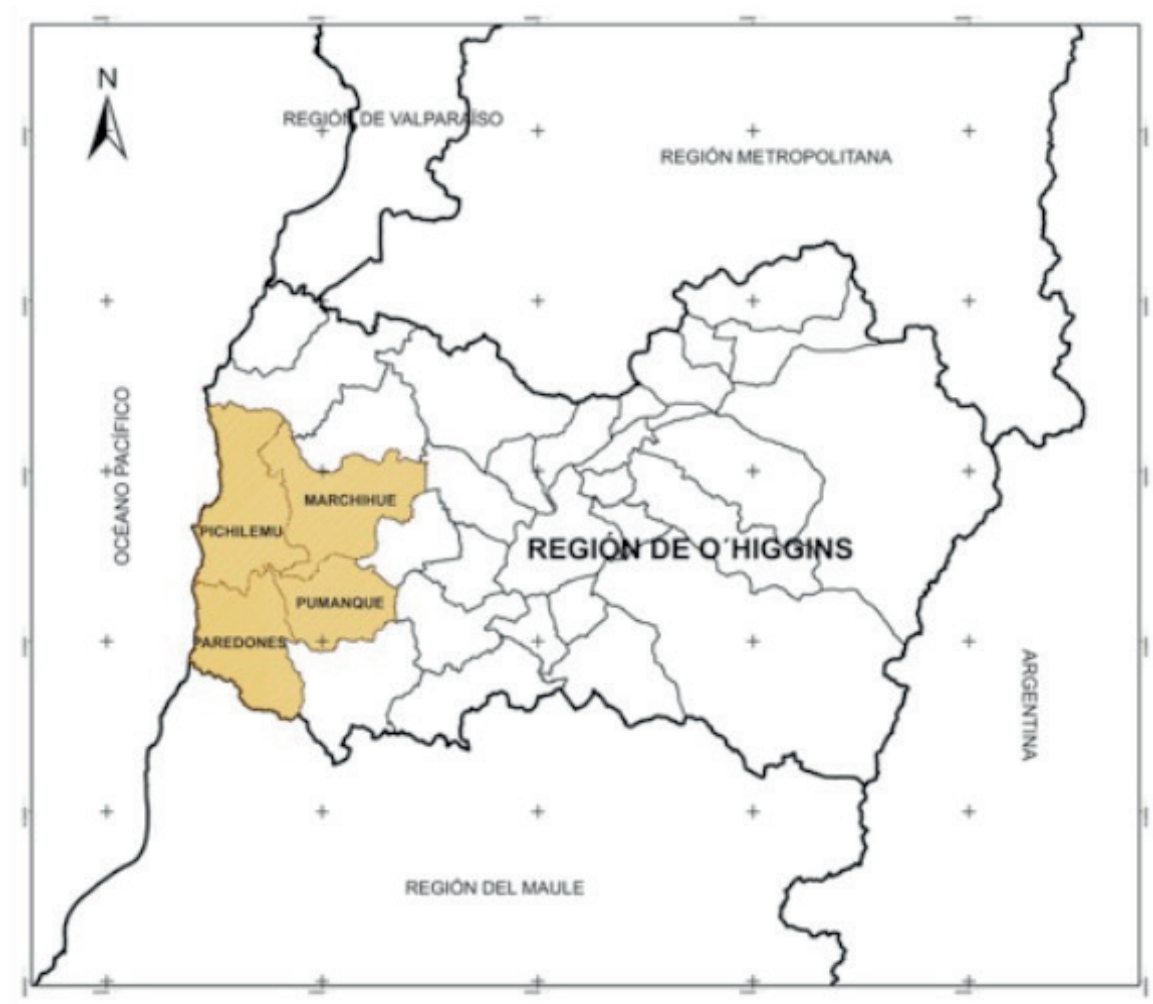

Figure 1: Study area, O’Higgins region. 
companies, farming industries) to supplement their salaries. Most of these individuals are older farmers (65 years of age on average). Quinoa seeds are obtained in $38 \%$ of cases from a family member, and $46 \%$ are obtained from farming neighbors (FAO, 2014).

Quinoa farming in the studied area corresponds almost entirely to family farming. In addition, it is a minor crop in terms of national relevance; nonetheless, 375 hectares are used for quinoa farming, representing the most extensive area in Chile.

\section{Conceptual Model}

The conceptual model of the MCDA used in this study takes into account economic and productive factors as a basis for a promoting strategy. Environmental, organizational, political, and cultural factors are also taken into account to enhance competitiveness based on soil sustainability. The methodology used in this study reflects a decision-making process that allows the performance of MCDA by sorting the information by hierarchical information according to each problem (Saaty, 1980). The conceptual model had three stages: I) identifying the criteria and interest groups, II) pairwise ranking of criteria, and III) pairwise ranking of crop alternatives. The development of the survey included the gathering of primary and secondary types of data sorted for developing and managing a database. The MCDA involved the assessment, prioritization, and number allocation for the quantification of criteria weighting. Factor inclusion followed an analytic hierarchy process (AHP) (Pantoja et al., 2017).

Different sources of opinion were used to guide the criteria for the sustainability of quinoa as a crop in the O'Higgins region. For the MCDA, the multiple criteria and crop alternatives were combined because data are a qualitative and quantitative representation. Therefore, a nor- malization process was conducted according to a value function and the conversion of criteria weighting, as described in Saaty (1980).

\section{Identifying The Criteria And Interest Group}

The identification of crop alternatives was based on the production statistics from the four listed towns in the O'Higgins region (INDAP, 2015). The weighting criteria of this study were based on previous studies carried out by Chavez et al. (2012), Rozman et al. (2014), Ayala (2013) and Fuentes et al. (2012). Additionally, other criteria related to the actual production of the studied area were included. Once the criteria were chosen, a weighting process was carried out using surveys administered to the interest group. They were conducted in person to better explain the objective of the study and to describe in detail how the questionnaires should be filled out. The parties involved were asked to give their opinion to weight the criteria that define the higher sustainability of quinoa crops over wheat crops.

The primary requirement to be part of the interest group was to have at least five years of knowledge or expertise in quinoa and wheat crops in the studied area. There were 20 participants in the study. Their opinions were used to weight the criteria; in turn, these criteria were used to weight the crop alternatives. The interest group consisted of eight farmers, three technical professionals, four government officials, and five scholars.

\section{Pairwise Ranking Of Criteria}

In the MCDA conducted in this study, the goal was to identify the sustainability criteria for quinoa crops over wheat. The criteria defined in the previous stage were weighted by the interest group, taking into account the crop alternatives in the studied area. Quinoa was represented as a booming farming product, while wheat was represented as a traditional one (Table 1). 
Table 1: Relevant information on crop alternatives.

\begin{tabular}{|c|c|c|}
\hline Ítems & Quínoa & wheat \\
\hline Variety & peasant & Maqui - INIA \\
\hline Performance (qq / ha) & 40 & 35 \\
\hline Sale date & March & January \\
\hline Expected price (\$ / QQ) & $\$ 50.000$ & $\$ 18.500$ \\
\hline Production destination & Intermediary sales & Molino \\
\hline Contingency & Drought / Frost & Drought / Fros \\
\hline Labor (A) & $\$ 494.000$ & $\$ 30.000$ \\
\hline Machinery & $\$ 190.000$ & $\$ 149.500$ \\
\hline Supplies & $\$ 252.558$ & $\$ 165.500$ \\
\hline Others & $\$ 14.316$ & $\$ 15.000$ \\
\hline Total direct costs & $\$ 950.874$ & $\$ 369.000$ \\
\hline Incidentals (5\%) & $\$ 47.543$ & $\$ 18.450$ \\
\hline Total costs & $\$ 998.417$ & $\$ 387.450$ \\
\hline Expected revenue (C / VAT) & $\$ 2.000 .000$ & $\$ 647.500$ \\
\hline Economic results & $\$ 1.001 .583$ & $\$ 260.050$ \\
\hline
\end{tabular}

Source: FIA, 2018: Potencial competitivo de la quínoa Chilena. ODEPA, 2017: Estimación costo por hectárea del proceso productivo de la quínoa. INDAP, 2015: Technical supply for peasant family agriculture.

Cost represented in national currency (CLP)

Each criterion was compared to another, and all comparisons were performed in pairs to assign a numeric value to each of these interactions (Barredo, 1996). The value was obtained from an absolute scale used to assign a numeric estimation (Bustillos, 2007). This estimation uses a verbal scale as a guide, ranging from 1 to 9 (Table 2). When comparing one criterion with another, the number 1 from the verbal scale means that both criteria are of equal importance. In turn, the number 9 on the verbal scale means that a criterion is completely more important than the other one. Numbers ranging from 2 to 8 represent intermediate importance.

The set of the weightings created by the interest group is represented in a pairwise matrix that takes into account the comparisons process of all the previously mentioned criteria. The weighting value is related to the importance given by the participants, and it was calculated based on the addition of the weighting values of the criteria. These values were assigned to columns; in turn, these columns composed the pairwise matrix results.

\section{Pairwise ranking of crop alternatives}

Once the previous stage was completed, the normalization of the values was conducted using the AHP method described in Saaty (1990). This method allows the weighting of the criteria to be measured. As used in Pantoja et al. (2017), the decision rule was a weighted linear combination (WLC) (Figure 2) along with the calculating tool.

The consistency index is used to assess the matrix. Mendoza and Macoun (1999) state that a maximum consistency index of $10 \%$ is acceptable when the matrix has five or more criteria. 
Table 2. Scale if values used for criteria

\begin{tabular}{lll}
\hline Numerical & Scale Verbal & Interpretation \\
\hline 1 & Equal importance of both criteria & $\begin{array}{l}\text { The two variables contribute equally to the objective } \\
\text { Experience and judgment slightly favor one criterion } \\
\text { over the other }\end{array}$ \\
5 & Moderate importance of one criterion over the other & One of the criteria is strongly favorable \\
7 & Strong importance of one criterion over the other & One of the criteria is strongly dominant \\
$2,4,6,8$ & Extry strong importance of one criterion over the other & Evidence extremely favored one of the criteria \\
\hline
\end{tabular}

Source: Modified table elaborated based on Toscano et al. (2000) The Hierarchical Analysis process (PAJ) as a tool for decision making in the selection of suppliers.

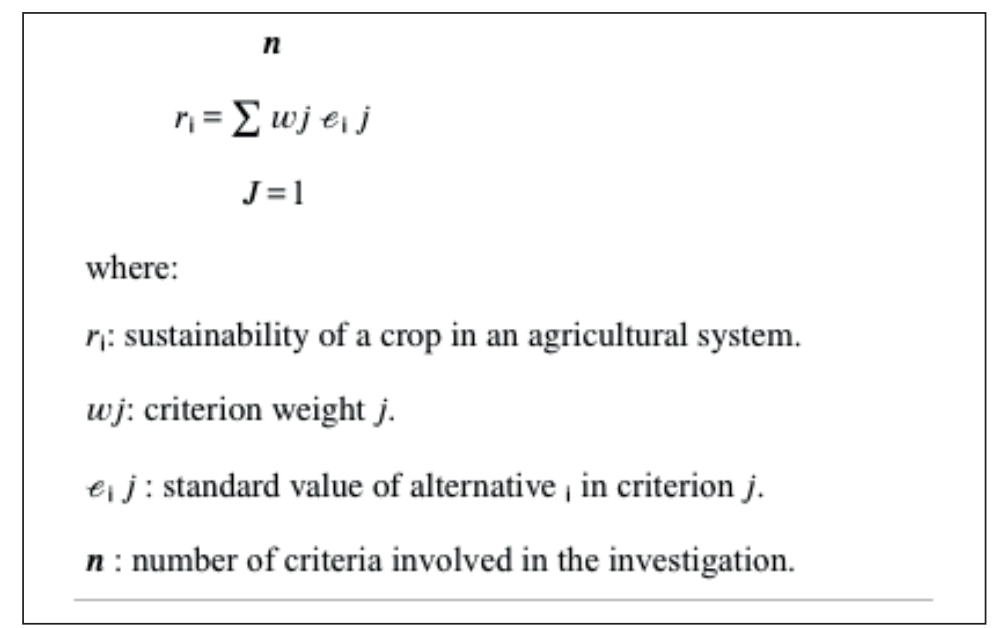

Figure 2: Linear Combination Weight.

This method allows synthesizing information and creating a hierarchy of priorities of the criteria regarding the crop alternatives (Figure 3). Regarding the global preferences of the interest group, we observed differences in criterion weightings depending on the competence and expertise of the people surveyed that formed part of the interest group (Chavez et al., 2012; Saaty, 1980).

\section{Results And Discussion}

\section{Identifying The Criteria And Interest Group}

To assess the sustainability of the quinoa crop, economic, cultural and environmental factors were taken into account. In the study, six criteria that met the requirements were selected. These criteria were involved directly or indirectly in quinoa and wheat crop farming.

On the other hand, the study area was chosen to gather information from a regular farming season without any adverse climate events. The following criteria were selected to be assessed by the interest group:

1. Contribution to family income: This represents the net income earned from harvest sales.

2. Ease of sales: This takes into account the facility and rapidity with which the harvest can be sold but does not take into account the selling price. 


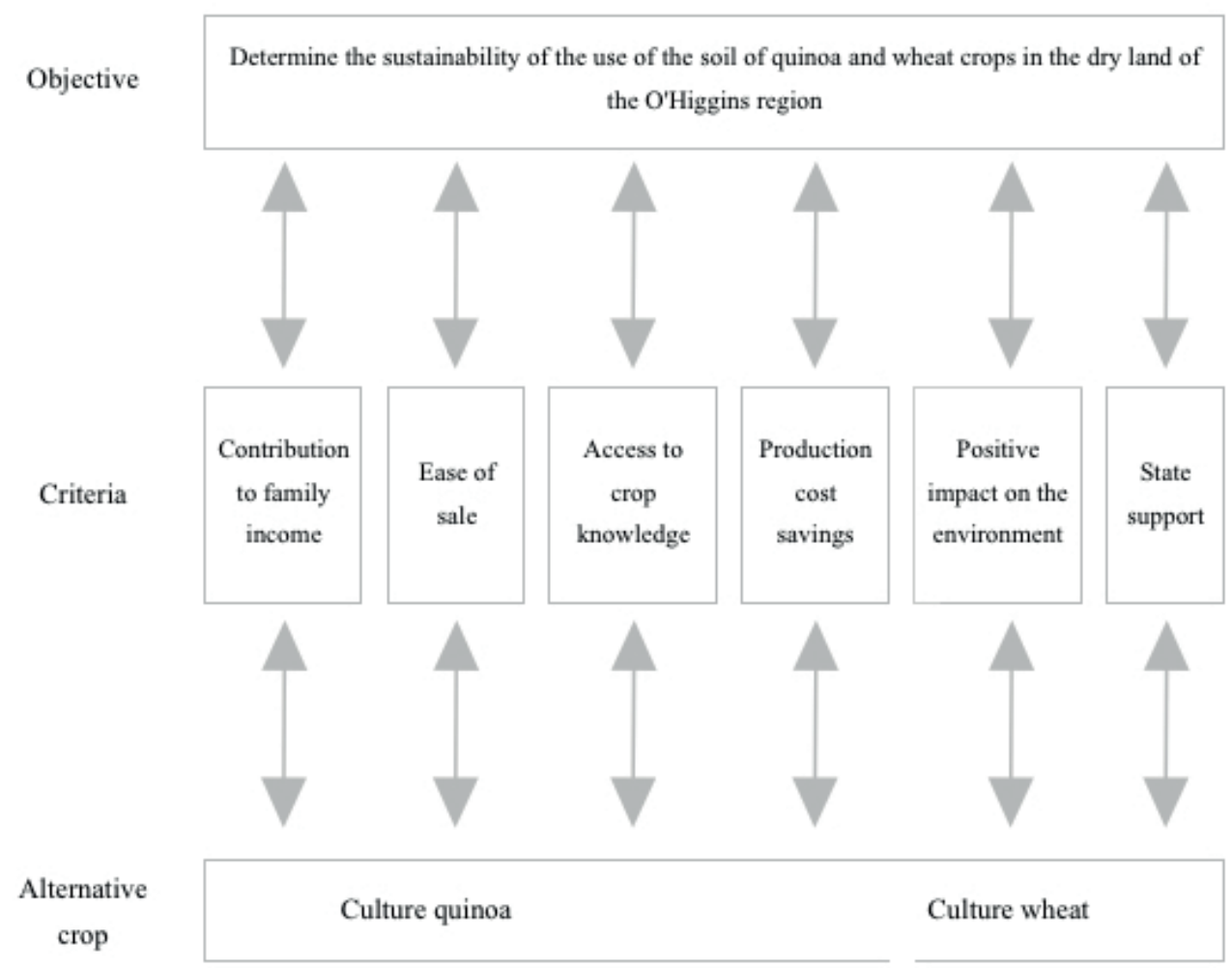

Figure 3: Competitiveness of quinoa and wheat crops.

3. Access of farmers to knowledge: This takes into account the information available to the farmers regarding the technical requirements of the crop so that it can grow.

4. Production costs savings: This takes into account the economic resources the farmers need to expend to farm a crop.

5. Positive impact on the environment: This refers to the widespread perception that farming a crop has a negative impact on the environment, mainly from the use of agrochemicals, water requirements, and impacts on soil quality.

6. Government support: This represents the technical support services, subsidies, and investments that farmers receive from public institutions for farming a crop.

\section{Pairwise Ranking Of Criteria}

Table 3 shows criteria weighting regarding the categories that was undertaken by the surveyed expert group. As previously mentioned in the methodology of the study, the weightings were extracted from the survey tool, which categorizes the values in three ranges: high weighting, ranging from 0.287 to 0.320 ; medium weighting, from 0.143 to 0.286 ; and low weighting, from 0.000 to 0.142 .

The criteria related to market logic were predominant in the weighting by the expert group; "contribution to family income" was the most important criterion in three out of the four categories considered by the interest group. The average of all of the weightings for this criterion was 0.320 . The valuation of this criterion can be explained by the necessity of small farmers to generate 
income and the availability of land in the land use of the rainfed area when choosing one crop over another. In this regard, the "ease of sale" was the criterion that was the second most highly weighted by the interest group (0.184). Farmers consider the prospect of selling the harvest fast to be a positive scenario.

The criteria with a medium weighting were "production costs savings" and "positive impact on the environment." The former was weighted 0.179 . These weightings are explained by the fact that the farmers need to bear the investment for farming the crop and expect a higher return than the money invested. It is worth mentioning that the investment needed for farming this crop is higher than that for farming other types of crops. The latter criterion had an intermediate weighting (0.272). Although an interest in the environment was observed, the criteria related to crop selling and marketing received higher weighting.

The criteria with the lowest weights were "access of farmers to knowledge" and "government support," with weights of (0.072) and (0.074) respectively. This indicates that these criteria are less relevant when opting for one crop over another.

\section{Pairwise Ranking Of Crop Alternatives}

According to the findings shown in Table 4, quinoa farming was weighted 0.454 in regard to preference. Three criteria were identified in which quinoa was weighted over wheat: contribution to family income, production costs saving and positive impact on the environment. The most significant gap, in which quinoa was chosen over wheat, was the "contribution to family income" criterion, with a gap of 0.270 . The higher price quinoa explains this, with ever-growing demand. The criterion "production costs savings" also showed a relevant difference in weighting: 0.222. This is explained by the fact that quinoa crops require less cost in terms of inputs to be farmed. Finally, the interest group weighted quinoa crops as having a higher "positive impact on the environment" than wheat crops.

Wheat crops received higher weights in three criteria (Table 4): government support, access of farmers to knowledge and ease of sale. The most significant gap was found in the government support criterion, with the weighting of wheat being 0.500 over that of quinoa. Unlike for wheat crops, quinoa farmers can only apply

Table 3: Weighting of criteria with respect to each group of experts.

\begin{tabular}{|c|c|c|c|c|c|c|c|}
\hline & $\begin{array}{l}\text { Contribution } \\
\text { to family } \\
\text { income }\end{array}$ & Ease of sale & $\begin{array}{c}\text { Access } \\
\text { to crop } \\
\text { knowledge }\end{array}$ & $\begin{array}{l}\text { Production } \\
\text { cost savings }\end{array}$ & $\begin{array}{c}\text { Positive } \\
\text { impact on the } \\
\text { environment }\end{array}$ & State Support & Weighing \\
\hline $\begin{array}{l}\text { Contribution to } \\
\text { family income }\end{array}$ & 1 & 4 & 7 & 3 & 7 & 3 & 0.320 \\
\hline Ease of sale & $1 / 4$ & 1 & 4 & 3 & 3 & 3 & 0.184 \\
\hline $\begin{array}{l}\text { Access to crop } \\
\text { knowledge }\end{array}$ & $1 / 7$ & 4 & 1 & $1 / 7$ & $1 / 5$ & $1 / 4$ & 0.072 \\
\hline $\begin{array}{l}\text { Production cost } \\
\text { savings }\end{array}$ & $1 / 3$ & $1 / 3$ & 7 & 1 & 2 & $1 / 5$ & 0.180 \\
\hline $\begin{array}{l}\text { Positive impact on } \\
\text { the environment }\end{array}$ & $1 / 7$ & $1 / 3$ & 5 & $1 / 2$ & 1 & 5 & 0.168 \\
\hline State Support & $1 / 3$ & $1 / 3$ & 4 & 5 & $1 / 5$ & 1 & 0.075 \\
\hline $\begin{array}{l}\text { Consistency ratio } \\
=0,5 \%\end{array}$ & & & & & & & \\
\hline
\end{tabular}


Table 4: Final weighting of crop alternatives.

\begin{tabular}{lccccccc}
\hline Crop Alternatives & $\begin{array}{c}\text { Contribution } \\
\text { to family } \\
\text { income }\end{array}$ & $\begin{array}{c}\text { Ease of } \\
\text { sale }\end{array}$ & $\begin{array}{c}\text { Access } \\
\text { to crop } \\
\text { knowledge }\end{array}$ & $\begin{array}{c}\text { Production } \\
\text { cost savings }\end{array}$ & $\begin{array}{c}\text { Positive } \\
\text { impact on the } \\
\text { environment }\end{array}$ & $\begin{array}{c}\text { State } \\
\text { support }\end{array}$ & $\begin{array}{c}\text { Global weighting } \\
\text { of the crop }\end{array}$ \\
\hline Quinoa & 0.611 & 0.362 & 0.287 & 0.635 & 0.579 & 0.250 & 0.454 \\
Wheat & 0.389 & 0.638 & 0.713 & 0.365 & 0.421 & 0.750 & 0.546 \\
Weighting distance & 0.222 & 0.276 & 0.426 & 0.270 & 0.158 & 0.500 & 0.092 \\
\hline
\end{tabular}

for the government support of the Chilean system for promoting the environmental sustainability of degraded soil (Sistema de Incentivos para la Recuperación de Suelos Degradados, SIRSD in Spanish initials) from the National Institute of Farming Development (INDAP in Spanish initials). This is a definite disadvantage when opting to farm quinoa instead of wheat. The latter has many direct funding systems. This trend can also be found in the "access of farmers to knowledge" criterion, with wheat being weighted over quinoa by 0.426 . This result can be explained by the local farming culture, in which there is a higher transfer of expertise from wheat farming. There is also a deeper knowledge of each stage in the productive chain that the crop requires. Finally, the third criterion for which wheat crops had a higher weighting is "ease of sale." The higher demand for wheat explains this. The issue observed was the ability to obtain a fair price, not to find a market to sell the crop.

It is publicly known that farmers, technical professionals, government officials, and scholars have positive expectations for quinoa farming, mainly because of two characteristics of this crop: adapt- ability to adverse agro-climate conditions and price expectations, as explained in Fuentes et al. (2009). That is why the findings showed that even though quinoa can contribute to family income, access to a market is hard. This demonstrates the gap or crucial point at which the parties involved must focus their efforts to promote quinoa farming in the studied area.

During the review of the bibliographical precedents, in a study carried out by Chavez et al. (2012), five criteria were proposed for tobacco farming reconversion. The criterion that obtained the highest weighting coincides with our study regarding high economic impact and the ease of sale issue. Both studies indicate that the market is an essential factor when assessing the sustainability of a crop.

According to the findings of this study, we conclude that different weightings are related to the six criteria taken into account by the MCDA methodology. Even though the surveys showed trends regarding higher or lower priority, different weightings in criteria were observed depending on the parties that form the expert group.

\section{Resumen}

P. Olguín, A. De Kartzow, y C. Huenchuleo. 2019. Sostenibilidad de la quinua en los sistemas agrícolas de secano: Un estudio de caso sobre la región de O'Higgins, Chile. Cien. Agr. 46(2): 197-207. La quinua es un grano que ha experimentado un rápido auge de consumo en los últimos años. Chile también ha seguido esta tendencia a través del consumo de quinua asociado a una dieta saludable y al cuidado del medio ambiente. La correlación entre el cultivo de la quinua y la sostenibilidad de la agricultura radica principalmente en las acciones y conocimientos de los agentes involucrados en el proceso de toma de decisiones, que dependen de la experiencia y los conocimientos disponibles. El análisis de decisiones multicriterio es un conjunto de técnicas de apoyo en el proceso de toma de decisiones. Consiste 
en dirigir múltiples opiniones y criterios de evaluación, en acciones concretas, validadas por un grupo de interés. Este estudio se basa en la definición y ponderación de los criterios que influyen en la sostenibilidad de la quinua como cultivo, en contraste con el trigo como el cultivo más importante en la zona de secano, teniendo en cuenta las opiniones de los agricultores y otras partes involucradas. Los resultados son la ponderación de los criterios de las siguientes variables: contribución a la renta familiar, facilidad de venta, impacto positivo en el medio ambiente, ahorro de costes de producción, conocimiento del cultivo y ayudas públicas. El modelo ayudó a crear una base cuantitativa para el potencial de sostenibilidad de la quinua como cultivo en auge y como alternativa al cultivo tradicional de trigo en la agricultura.

Palabras clave: Ecosistema, reconversión, ventaja comparativa.

\section{Reference}

Alfonso, D. 2008. La gestion de la biodiversité par les paysans: Le quinua au Chili». Tesis de Master 2, Spécialité Recherche: Innovations et Développement des Territoires Ruraux. SupAgroIAMM-UMIII-CIRAD, Montpellier-Francia.

Ayala, F. 2013. Desarrollo de estrategias de posicionamiento. Caso: Producto Quinua". Perspectivas, Año 16-Na32-Octubre 2013. Universidad Católica Boliviana "San Pablo", Unidad Académica Regional Cochabamba. p. 39-60.

Barredo, C. 1996. Sistemas de Información Geográfica y Evaluación Multicriterio en la Ordenación del Territorio. Editorial RA-MA. Madrid, España. p. 259.

Bazile, D., F. Fuentes and A. Mujica. 2013: Hitorical perspective and domestication. In: Bahargava Atul, Srivastava Shilpi. Quinoa: botany, production and uses. Wallingford: CABI, p.16-35.

Bustillos, J., J. Valdez, A. Alderete, and M. Gonzalez. 2007. Aptitud de terrenos para plantaciones de eucalipto (eucalyptus grandis hill ex maiden): definición mediante el proceso de análisis jerarquizado y SIG.

Chavez, M., P. Berentsen, and A. Oude. 2012. Assessment of criteria and farming activities for tobacco diversification using the Analytical Hierarchical Process (AHP) technique. Agricultural Systems Vol 111, Septiembre 2012, p. 53-62.

Di Castri, F., and E. Hajek. 1976. Bioclimatología de Chile. Santiago, Chile: Ediciones de la Universidad Católica de Chile. 128 pp.
FAO. 2014. Estado del arte de la quinua en el mundo. Número V: Quínoa in Chile. IN: BAZILE D. et al.: FAO (Santiago de Chile) y CIRAD, (Montpellier, Francia): pp. 397-430.

FIA 2017. Potencial competitivo de la quinua chilena. Fundación para la Innovación Agraria. Santiago, Chile. Primera edición, noviembre 2017. ISBN No 978-956-328-202-3. pp. 36-42.

Fuentes, F., D. Bazile, A. Bhargava and E. Martínez. 2012. Implications of farmers' seed exchanges for on-farm conservation of quinua, as revealed by its genetic diversity in Chile. Journal of Agricultural Science, 2012, $\mathrm{N}^{\circ}$ 150: p.702-716.

Fuentes, F., E. Martínez, P. Hinrichsen, E. Jellen and P. Maughan. 2009. Assessment of genetic diversity patterns in Chilean quinua (Chenopodium quinua Willd.) germplasm using multiplex fluorescent microsatellite markers. Conservation Genetics, Vol. 10 (2), p. 369-377.

Fuentes, F. 2008. Quinua: Recurso Fitogenéticos y su uso en la agricultura. Revista Agricultura del Desierto (4). ISSN: 0717-2729. p. 82-101.

INDAP. 2015. Suministros técnicos para la agricultura familiar campesina temporada 2015-2016. Macro Zona Central. Instituto Nacional de Desarrollo Agropecuario, Ministerio de Agricultura, $\mathrm{N}^{\circ} 1$, tomo 2 Septiembre 2015. p 114.

Malczewski, J. 2006. GIS-based multicriteria decision analysis: a survey of the literature. Int J Geogr Inf Sci 20(7):703-726.

Mendoza, G., and P. Macoun. 1999. Guidelines for Apllying Multi-Criteria Analysis to the Assess- 
mnet of Criteria and Indicators. Journal Forest Ecology and Management 207:145-146.

Pantoja, G., M. Gómez, C. Contreras, L. Grimau, J.F. Ramírez, and G. Montenegro. 2017. Determination of suit- able zones for apitourism using multicriteria evaluation in geographic information systems: a case study in the O'Higgins Region, Chile. Cien. Inv. Agr. 44(2):139-153.

Pefaur, J. 2018. La Quínoa en Chile, el despegue de un grano ancestral. Enero de 2018. Departamento de Análisis de Mercado y Política Sectorial.
Artículo producido y editado por la Oficina de Estudios y Políticas Agrarias - Odepa-. Ministerio de Agricultura de Chile.

Rozman, Č., M. Hühner, M. Kolenko, S. Toinko, T. Unuk, and K. Pažek. 2015. Apple Variety Assessment with Analytical Hierarchy Process. Erwerbs-Obstbau, 57(2), p. 97-104.

Saaty, T. 1990. "How to Make a Decision," European Journal of Operational Research, 48: p.9-26

Saaty, T. 1980. The Analytical Hierarchical Process. Wiley, New York 